\title{
A Perspective on Sea Level Rise and Coastal Storm Surge from Southern and Eastern Africa: A Case Study Near Durban, South Africa
}

\author{
Andrew A. Mather ${ }^{1,2, *}$ and Derek D. Stretch ${ }^{2}$ \\ 1 Ethekwini Municipality, 166 K.E. Masinga Road, Durban 4001, South Africa \\ 2 Centre for Research in Environmental, Coastal and Hydrological Engineering, University of \\ KwaZulu-Natal 4041, South Africa; E-Mail: stretchd@ukzn.ac.za \\ * Author to whom correspondence should be addressed; E-Mail: mathera@durban.gov.za; \\ Tel.: +27-31-3117281; Fax: +27-031-3056952.
}

Received: 3 February 2012 / Accepted: 20 February 2012 / Published: 5 March 2012

\begin{abstract}
Recent coastal storms in southern Africa have highlighted the need for more proactive management of the coastline. Within the southern and eastern African region the availability of coastal information is poor. The greatest gap in information is the likely effects of a combination of severe sea storms and future sea level rise (SLR) on the shoreline. This lack of information creates a barrier to informed decision making. This research outlines a practical localized approach to this problem, which can be applied as a first order assessment within the region. In so doing it provides a cost effective and simple decision support tool for the built environment and disaster professionals in development and disaster assessments. In a South African context the newly promulgated Integrated Coastal Management Act requires that all proposed coastal developments take into consideration future SLR, however such information currently does not exist, despite it being vital for informed planning in the coastal zone. This practical approach has been applied to the coastline of Durban, South Africa as a case study. The outputs are presented in a Geographic Information System (GIS) based freeware viewer tool enabling ease of access to both professionals and laypersons. This demonstrates that a simple approach can provide valuable information about the current and future risk of flooding and coastal erosion under climate change to buildings, infrastructure as well as natural features along the coast.
\end{abstract}


Keywords: climate change; coastal erosion; flooding; hazards; sea-level rise

\section{Introduction}

In recent years, much work has been done on global climate change and the likely impacts that may arise from this change [1-6]. However, relatively little research on climate change has been undertaken for the African continent and in the southern and eastern African region to date, with the exception of South Africa. Climate change impacts are likely to affect many different aspects of the world's environment. However, this paper focuses on coastal flooding hazards, both now and under future sea-level rise (SLR) along the southern and eastern African shoreline.

In South Africa, amid increased awareness and concern of climate change and SLR, several government agencies have commissioned research in these areas. Studies of SLR in Durban [7] and SLR in Namibia and South Africa [8] and regional impacts of climate change in the Western Cape [9] have recently been completed. Three of South Africa's major coastal cities, Durban [10-14], Cape Town [15] and Port Elizabeth have embarked on studies to understand and address these impacts. Research institutions are now also contributing [16-18]. Within Africa, outside of South Africa there has been even less research work done although Mozambique has initiated discussions and projects on SLR $[19,20]$.

While this new impetus is encouraging, the capacity of governments, regions, cities and communities in Africa to proactively manage, mitigate and adapt to the impacts of climate change has been a concern in international circles [21]. This concern arises due to the high mitigation and adaptive costs that are likely to be required. The region is financially poor by world standards and very little funding is likely to be available for widespread interventions, which makes the challenge of dealing with climate change and SLR even more difficult. In reality, there is limited scope for mitigation of climate change and therefore efforts must be concentrated on adaptation. In order to adapt for the future, it is important to understand the nature and significance of possible threats. Without any understanding of the possible risks, any adaptation interventions run the risk of being mis-directed.

\section{Problem Statement}

The southeastern coastline of southern Africa, comprising South Africa, Mozambique, Tanzania and Kenya, is regularly affected by cyclonic and other significant weather events that have the ability to unleash large wave events along the coast. The impacts of climate change and SLR are likely to exacerbate the existing problems of coastal flooding and erosion [14]. Much of this coastline comprises sandy beaches backed by flat low coastal plains that are already vulnerable to flooding and erosion in extreme wave events. Progressive SLR will worsen the situation but it is the episodic wave events, occurring with little advanced warning that results in significant flooding and erosion.

In order to plan for these hazards some baseline data is needed. The reality is that countries in this region do not have spare funds to generate this data and so it is unlikely that in the foreseeable future data that would meet first world standards will be collected. However, historical data on cyclone events are available [22]. There are tide gauges in the region but with inadequate spatial coverage and 
of those stations that have tide data they are for relatively short durations that prevent high confidence sea-level change trends from being deduced [23]. There is very limited coastal erosion and shoreline change data along this coast as pointed out earlier and that is unlikely to change given human resource capacity, skills and funding limitations.

Under these circumstances it is essential that a simple, practical approach to identifying the coastal flooding hazard zone be applied. The method must be easy to use and conservative enough to help coastal managers identify the flooding and erosion hazard zones. The objective of this paper is to demonstrate this by identifying the regional hazards and then applying a simple model that informs the extent of the coastal flooding hazard zone in the region between Mombasa and Cape Town, a distance of over $6000 \mathrm{~km}$ in length. Mombasa and Cape Town were selected as the ends of the region as both sites have functional tide gauges. Tide information is a vital input into determining the impact of wave events since storms occurring at low tide cause less damage than storms occurring at high tide. In order to demonstrate the approach it was decided to work with a manageable length of coastline. As the authors are based in Durban and the first author is employed by the eThekwini municipality, it was logical to choose the eThekwini municipal coastline, approximately $100 \mathrm{~km}$ in extent, as the case study (Figure 1).

Figure 1. Regional map with place names referred to in the text. The case study is located in Durban (Source: Adapted from NASA [24]).

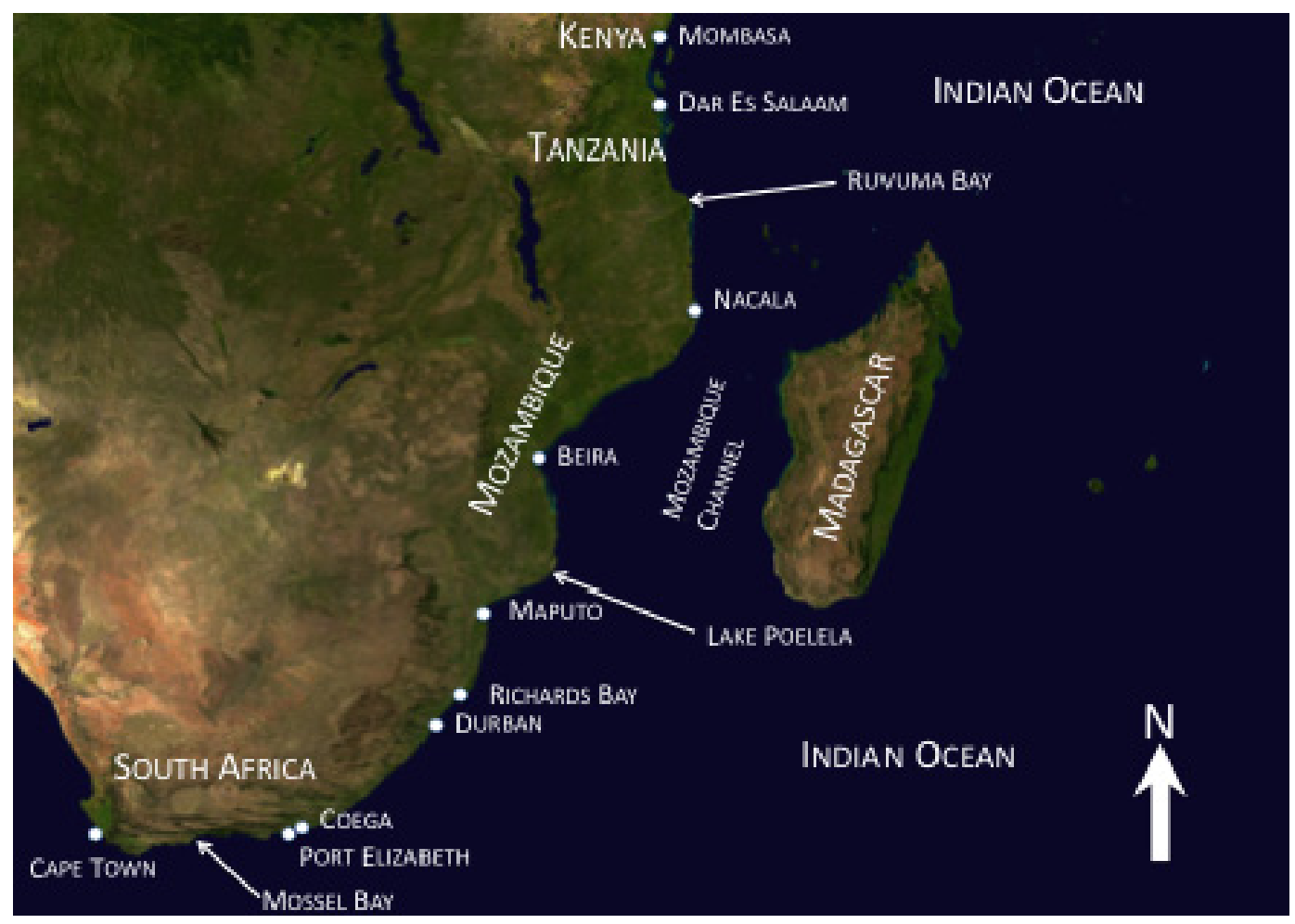

\section{Coastal Flooding, Erosion and Wave Hazards in the Region}

\subsection{Weather Systems}

The southern African coastline is intermittently impacted by extreme swells associated with tropical cyclones (which are also referred to as hurricanes in the North Atlantic and typhoons in the eastern 
Pacific Oceans) and cut-off low-pressure systems [25].

In the eastern Indian Ocean, cyclones generally form to the east of Madagascar. Most of the time they move in a west-south-westerly direction towards the African continent. Some make their way across Madagascar into the Mozambique Channel, while others move southward. The majority of tropical cyclones track in a south-easterly direction, away from the mainland, and back towards the Indian Ocean. It is these cyclones which turn south-easterly and sometimes remain semi-stationary south of Madagascar that are the ones that cause the biggest swells in the region.

Occasionally tropical cyclones do make landfall and can devastate the coastal zone in its path (Figure 2).

Figure 2. Tracks of all tropical cyclones in the Southwest Indian Ocean from 1980 to 2005. $90^{\circ} \mathrm{E}$ longitude is marked (vertical blue line) as this is the eastern boundary of the basin. The points show the locations of the storms at six-hourly intervals (Source: Wikimedia Commons [26]).

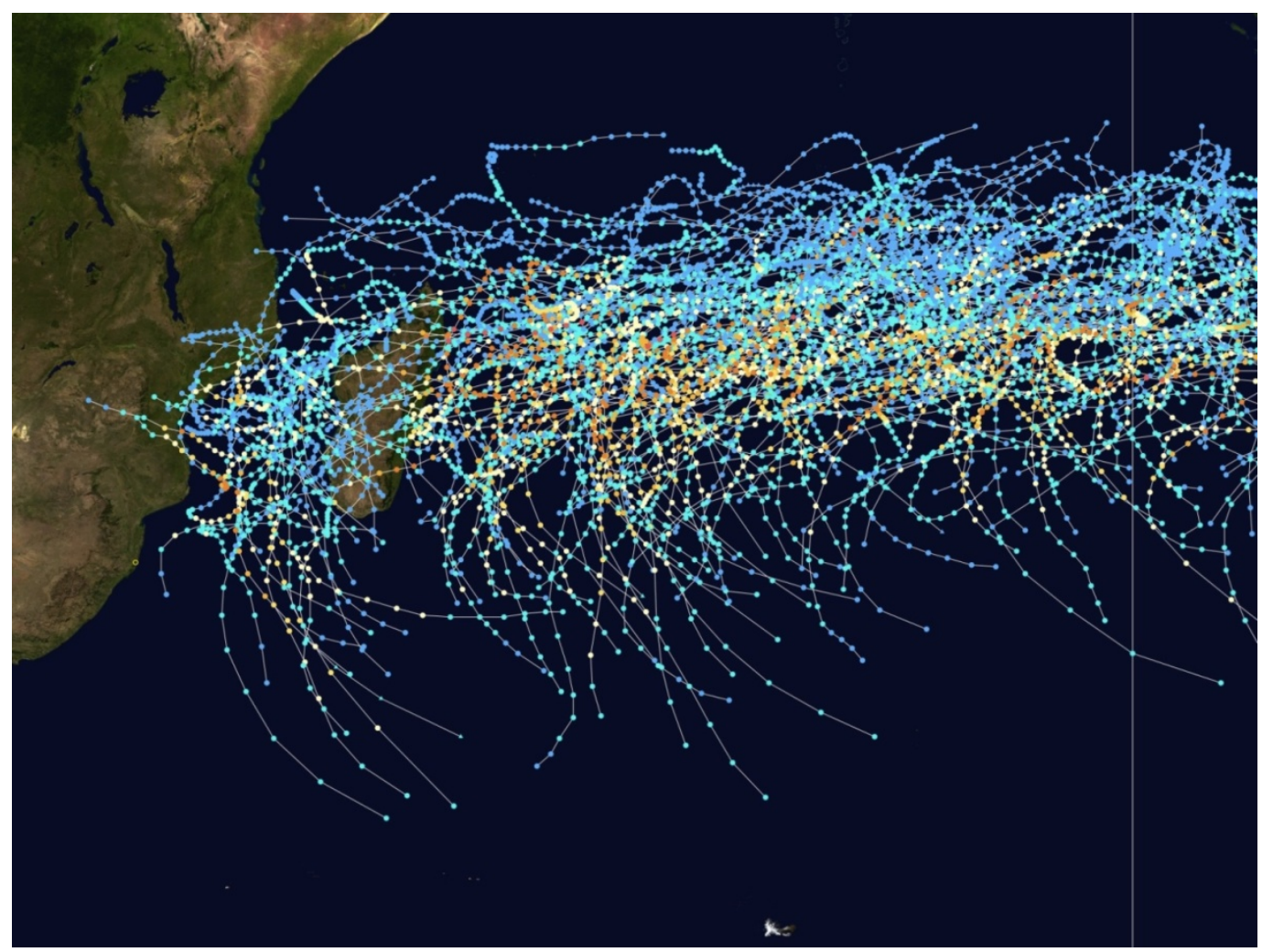

One such event, Tropical Cyclone Domoina, occurred in January 1984 and made landfall near Maputo, Mozambique causing extensive wind and rainfall damage. Tropical cyclones typically occur in the summer months but are most frequent in January, February and March, which is also when the tides lead up to the equinox (March/April) as shown in Table 1 [25].

Table 1. Monthly frequency of the 934 tropical cyclones since 1848 in the Southwest Indian Ocean [25].

\begin{tabular}{cccccccccc}
\hline Month & September & October & November & December & January & February & March & April & May \\
\hline$\%$ & 1 & 2 & 3 & 13 & 30 & 26 & 17 & 6 & 2 \\
\hline
\end{tabular}


In contrast, cutoff lows are generated in the Southern Oceans when an anti-cyclonic depression occurs as a result of strong upper ridge advancing southeastwards and separating a cold upper air pool. They are characterized by a convex shaped surface high-pressure system along the southern Cape coast [27]. The formation of cut-off lows over land are not uncommon, however, these rarely result in high seas.

An intense cyclonic mid-latitude system is often referred to as an extra-tropical or mid-latitude cyclone, and is normally associated with a cold front that follows a strong ridge of the Atlantic high-pressure system. Cold fronts are often preceded by coastal lows, which are typically responsible for the southwesterly winds along the east coast of Southern Africa. Well-formed cold fronts can generate significant swell. The passage of this type of system results in gale force winds and high seas [27]. When these weather systems coincide with spring high tides they set the scene for exceptional flooding and erosion.

\subsection{The March 2007 Storm in KwaZulu-Natal, South Africa}

\subsubsection{Conditions Preceding the Storm}

Sea conditions had been unusual in the months leading up to this event as the region had been affected by three cyclonic events, Dora, Favio and Gumede. Cyclone Dora, which combined with a well developed cold front to the south of the country, resulted in 2-3 m swells and impacted the KwaZulu-Natal coastline from 11 to 13 February 2007. Cyclone Favio, which generated $185 \mathrm{~km} / \mathrm{h}$ winds within $37 \mathrm{~km}$ of the center and significant wave heights above $14 \mathrm{~m}$ [28], moved from the south of Madagascar, through the Mozambique Channel, making landfall in Mozambique The cyclone generated high seas in Mozambique and heavy rainfall in south-eastern Zimbabwe and southern Malawi. However, it did not produce large wave heights along the KwaZulu-Natal coastline [29]. Cyclone Gamede closely followed and although downgraded from a tropical cyclone to an extra tropical depression, remained relatively stationary between the 2 and 5 March and created localized flooding along the KwaZulu-Natal coastline. However, Cyclone Gamede also depleted the beaches of their buffer of sand as the waves moved sand from the beaches into deeper water.

\subsubsection{Conditions During the Storm}

The weather system responsible for the March sea storm started as a frontal low, which passed south along the coast of South Africa on 16 March 2007. The frontal low intensified and rapidly developed into a cut-off low south-east of East London on 17 and 18 March. It intensified to a peak on the 19 March, where it remained trapped between two high-pressure cells until 20 March. The cut-off low started to weaken by midday on the 19 March and conditions had almost returned to normal by 20 March [30]. The central pressure of this cell dropped to below $986 \mathrm{hPa}$ at its peak. The strong pressure gradient generated strong and consistent winds. Wind speeds started picking up on the 17 March, recorded hourly wind speed rose to $10.9 \mathrm{~m} / \mathrm{s}$ (peak $10 \mathrm{~min}$ speed of $18.5 \mathrm{~m} / \mathrm{s}$ at $24 \mathrm{H} 00$ ), on the 18 March, the recorded hourly wind speed peaked at $11.9 \mathrm{~m} / \mathrm{s}$ (peak 10 min speed $22.1 \mathrm{~m} / \mathrm{s}$ (43 knots) at 14H10) and over the course of the 19 March subsided [31].

As the system was trapped in position this allowed the wind to generate some impressive waves 
straight at the coastline of KwaZulu-Natal for approximately 48 hours. Wave heights at Richards Bay, approximately $180 \mathrm{~km}$ north of Durban reached a significant wave height $\left(H_{m 0}\right)$ of $8.5 \mathrm{~m}$, with a peak single wave height of $14 \mathrm{~m}$. The event was felt along a stretch of coastline from Maputo $\left(25^{\circ} 58^{\prime} \mathrm{S}\right.$, $\left.32^{\circ} 34^{\prime} \mathrm{E}\right)$, Mozambique [32] to Port Elizabeth (335' $\left.\mathrm{S}, 25^{\circ} 38^{\prime} \mathrm{E}\right)$. Fortunately, the wave event very quickly dissipated and by the evening of 20 March, the swells had reduced to less than $3 \mathrm{~m} \mathrm{[30].}$

\subsubsection{Tide, Storm Surge and Wave Run Up Levels}

The Highest Astronomical Tide of the Year (HATOY) at $2.284 \mathrm{~m}$ above MSL ( $2 \mathrm{~cm}$ less then the Highest Astronomical Tide (HAT) of the 18.6 year cycle) was predicted to occur on the 19 March 2007 at 04H32 South African Standard Time (SAST). This event had already been forecast as having the potential to create widespread erosion should it coincide with a large wave event. The South African Navy tide gauge in Durban recorded a peak storm surge of $70 \mathrm{~cm}$ (3 min average). Wave run-up levels recorded along the beaches ranged between $+4 \mathrm{~m}$ and $+10.5 \mathrm{~m}$ above MSL [33]. Highest levels were recorded in open coastal locations where the bathymetry dropped off sharply.

\subsubsection{The Impact of the Storm}

The storm resulted in widespread damage to private and public infrastructure and homes along $\pm 400 \mathrm{~km}$ of coastline at an estimated cost of about US\$100 million [30]. Several homes were completely lost or damaged beyond economic repair and damaged sewer reticulation poured raw sewage into the sea for several months after the event prompting a bathing ban along many of the popular swimming beaches.

\subsection{The Likelihood and Magnitude of Future Storm Events and Sea Level Rise by 2100}

The threat of similar events in the future has been accepted [34] and therefore the attention has turned to developing a planning framework around these events. The goal is to reduce the flooding and erosion hazard associated with these events. With a coastline that has significant coastal development already in place, the task is made more difficult by the social and economic considerations associated with such decisions [35]. Kay and Alder [36] defined a hazard as "an event or process with potential harm to people, property and the environment". Their definition takes the concept of a risk, in other words the likelihood of occurrence of a defined event with no human or environmental consequences as a risk. Conversely, where there is the likelihood of occurrence of a defined event with human or environmental consequences this becomes a hazard. It is becoming clearer that this hazard will continue to be ever-present and may increase with ongoing climate change in the region [17].

\subsection{Past and Future Storm Activity}

The March 2007 event, while significant, was by no means unusual. Events of similar magnitude have occurred in the recent past. On the 13 June 1997 a cut-off low system off the coast of East London, South Africa created similar conditions to this storm. Significant wave heights of $9.3 \mathrm{~m}$ were only marginally higher but the effects were of similar erosion and property loss. Cyclone Imboa occurred in mid February 1984 off the coast of Maputo, Mozambique and created high winds and large 
waves with a significant wave height between 8 and $9 \mathrm{~m}$. During 1970, a wave event caused erosion and damage along the Durban coastline. In late May 1966, a sea storm with a significant wave height of approximately $8.5 \mathrm{~m}$ stripped the sand off the beaches along the coastline south of Durban, South Africa revealing a Quaternary fossil bed [37].

As has been previously pointed out, wave events along this coast are driven by the wind generated from cyclonic and cutoff low events. To generate the most erosive waves two factors must coincide. Firstly, high sustained winds blowing onshore and secondly, a suitably long fetch (the distance over which the wind can blow and in so doing, creating waves). Using the physical layout of the regional coastline as a starting point, potential maximum wave height using either fetch limited or duration limited wind speeds can be estimated using the Coastal Engineering Manual developed by the US Army Corps of Engineers [38]. On that basis the potential maximum wave height along the South African, Mozambique, Tanzanian and Kenyan coastlines have been calculated and are shown in Table 2.

Table 2. Potential maximum wave heights in the region calculated using the US Corps of Engineers Coastal Engineering Manual [38].

\begin{tabular}{ccccc}
\hline \multicolumn{2}{c}{ Coastal segment } & Duration limited & Fetch limited & Maximum regional \\
\cline { 1 - 3 } From & To & $\begin{array}{c}\text { Maximum wave } \\
\text { height generated by } \\
\text { wind duration(m) }\end{array}$ & $\begin{array}{c}\text { Maximum wave } \\
\text { height generated by } \\
\text { fetch length (m) }\end{array}$ & $\begin{array}{c}\text { wavser of duration or } \\
\text { fetch limited) }\end{array}$ \\
\hline $\begin{array}{l}\text { Cape Town } \\
\text { South Africa }\end{array}$ & $\begin{array}{l}\text { Mossel Bay } \\
\text { South Africa }\end{array}$ & 10 & 10 & $\mathbf{1 0}$ \\
\hline $\begin{array}{l}\text { Mossel Bay } \\
\text { South Africa }\end{array}$ & $\begin{array}{l}\text { Lake Poelela } \\
\text { Mozambique }\end{array}$ & 9 & 9 & $\mathbf{9}$ \\
\hline $\begin{array}{l}\text { Lake Poelela } \\
\text { Mozambique }\end{array}$ & $\begin{array}{l}\text { Ruvuma Bay } \\
\text { Mozambique }\end{array}$ & 9 & 8 & $\mathbf{8}$ \\
\hline $\begin{array}{l}\text { Ruvuma Bay } \\
\text { Mozambique }\end{array}$ & $\begin{array}{l}\text { Mombasa } \\
\text { Kenya }\end{array}$ & 10 & 10 & $\mathbf{1 0}$ \\
\hline
\end{tabular}

The wind speeds and fetch lengths in the Mozambique Channel are restricted by the proximity of Madagascar to the Mozambique coastline, effectively capping the maximum wave heights to $8 \mathrm{~m}$ (see Table 2). When these results are compared to other data, the results are similar. The Voluntary Observing Ships (VOS) observed wave height data from 1960-1999 that indicates only 0.1\% of the total 17,168 records exceeding $9.0 \mathrm{~m}$ at the southern tip of Madagascar [39]. Reduced wave heights in the Mozambique Channel have been reported by Theron [17].

\subsection{Sea Level Changes by 2100}

Various authors have used a variety of different factors and methods to predict future sea level change. The use of global climate change models [6], a temperature/SLR relationship [40], ice melt yield [41] and quadratic equation projections from tide records [42,43] are a few of the methods employed. Predicted rates and magnitude of future global SLR are still hotly debated but there is agreement that these will rise. Several countries have adopted SLR scenarios based on the work of the IPCC [6] and others, notably post 2007. For example, Germany has taken $1 \mathrm{~m}$ of SLR as the upper bound of potential SLR by 2100 [44]. The Dutch, with their extreme vulnerability to the impacts of 
SLR, have adopted a maximum SLR, excluding settlement, of $1.1 \mathrm{~m}$ by 2100 [45] and California has adopted a maximum of $1.4 \mathrm{~m}$ by 2100 [46].

Recent sea-level analysis in the region has shown that there is variation in the rate of sea-level change in the region $[7,8,47]$. Virtually all tide gauges show a rise with the exception of Zanzibar at $-3.6 \mathrm{~mm} / \mathrm{yr}$ ) [47]. For this particular case study, the observed SLR trend in Durban is $+2.7 \pm 0.05 \mathrm{~mm}$ per year [7] and for the eastern region of South Africa is estimated as $+2.74 \mathrm{~mm}$ per year [8].

In order to model the effects of any SLR several scenarios were chosen [48]. These scenarios have been determined as follows:

- Scenario 1: $300 \mathrm{~mm}$ based on current linear SLR

- Scenario 2: $600 \mathrm{~mm}$ based on doubling of the current SLR rate

- Scenario 3: 1,000 mm based on an accelerated ice melt scenario.

The last scenario was included since recent literature has suggested accelerated ice melt [49].

\subsection{High Water Mark and Wave Run Up}

An important factor in determining the hazard zone is the extent of wave run-up along the shoreline. Traditionally the coastline has a legally defined measure of wave run up, the High Water Mark (HWM). Generally these HWM's are a combination of a high tide level and storm wave run up. In most instances they are delineated following actual events, i.e., a land surveyor co-ordinates the position of the debris line and this is declared the HWM. These HWM's are not helpful in identifying the hazard zone, as they generally do not account for extreme waves in the order of 8 to $10 \mathrm{~m}$.

As waves approach a shoreline their shape and height changes and wave energy is lost to friction on the ocean floor. This can also causes a change in wave direction depending on the incident wave angle to the coastline. As the waves make their way inshore, the wave height increases until the wave breaks before reforming as a smaller wave that proceeds inshore. The surf zone (the area where the waves break) accounts for the majority of the loss of wave energy [50]. The wave then reaches the beach and the remaining wave energy is converted to potential energy in the form of run-up on the sloping face of the beach [51]. The run-up of the waves provide the energy needed to rework the beach slope, erode the dunes [52-55] and endanger any human-made structures in its path.

Planning for coastal impacts requires an understanding of the likelihood and extent of water/wave action and sea-level rise along the coast while considering its geological context as Jackson et al. $(2005,2009)[54,55]$ have pointed out. Intuitively one understands that the closer a structure is located to the sea the higher the risk of likely damage. The magnitude of wave run-up across and up the beach slope is therefore critical in understanding the extent of the potential coastal hazard zone for large wave events. However, the identification of this zone varies along the coastline depending on numerous factors relating to the beach, beach material, wave regime, wave direction and underwater bathymetry. Rising sea levels have the effect of lifting the Still Water Level (SWL) along the coastline and allowing more wave energy to move closer inshore and in so doing eroding the sandy coastline. If a sandy coastline is backed by human settlements then this process may present problems for these facilities.

Waves heights are generally recorded in an offshore location, i.e. in depths of water exceeding $30 \mathrm{~m}$. The offshore wave heights will be different to the inshore conditions particularly if the bathymetry is 
complex and/or the shoreline is not an open straight coastline. In the case of an open straight coastline the model of Mather et al. (2010) [33] is applicable. More complex coastlines will require models that include wave refraction, (such as Waves Nearshore or SWAN model) to provide inshore wave heights.

Wave run up levels can be calculated using a number of international wave run up models [56-59] however, as Mather et al. [33] have pointed out, the best of these international models do not predict the observed wave run-up very well along this coastline and therefore a new local model was developed for the case study area. This model will be used as the basis of the predicted wave run-up heights in this paper.

\section{High Water Mark and Coastal Flood Hazard Delineation Model: A Case Study of the Durban Coastline}

The case study that will be used to demonstrate the approach will be the entire municipal coastline of the eThekwini municipality as shown in Figure 3.

Figure 3. Map showing the eThekwini municipal coastline.

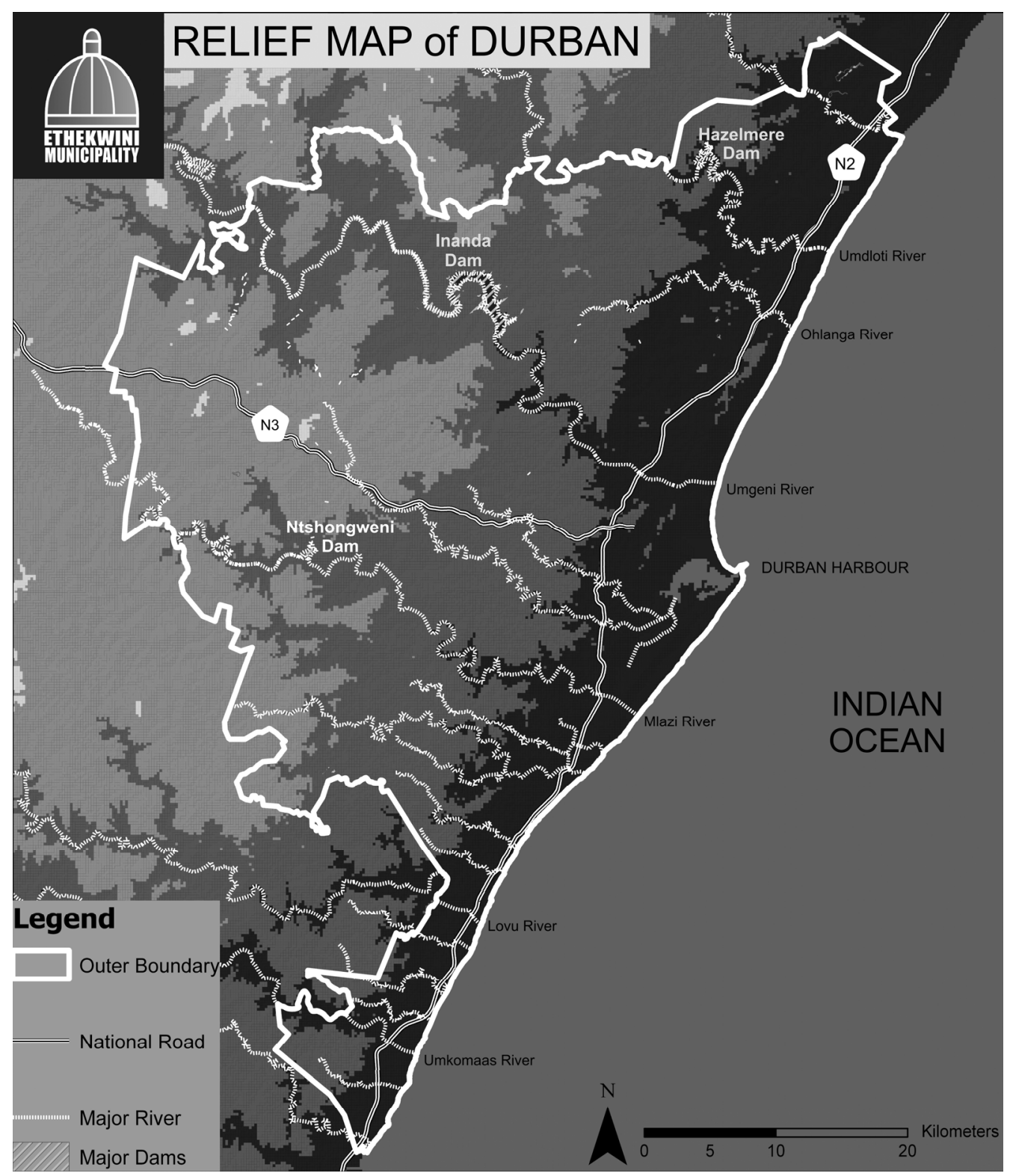




\subsection{The Model}

The model consists of two separate parts. The first part is to calculate the amount of wave run-up along the shoreline based on the offshore wave, bathymetry and the state of the tide. The second part is the determination of the extent of retreat of the coastline under differing SLR scenarios. In the preliminary assessment to decide which model to use, two models were considered; namely the Carter Roll-over model [60] and the Bruun Rule [61], as shown in Figure 4.

Figure 4. Cross-shore sections showing the application of the Carter [60] and Bruun [61] models. Original shoreline in solid black and sea level rise (SLR) modified shoreline in orange.

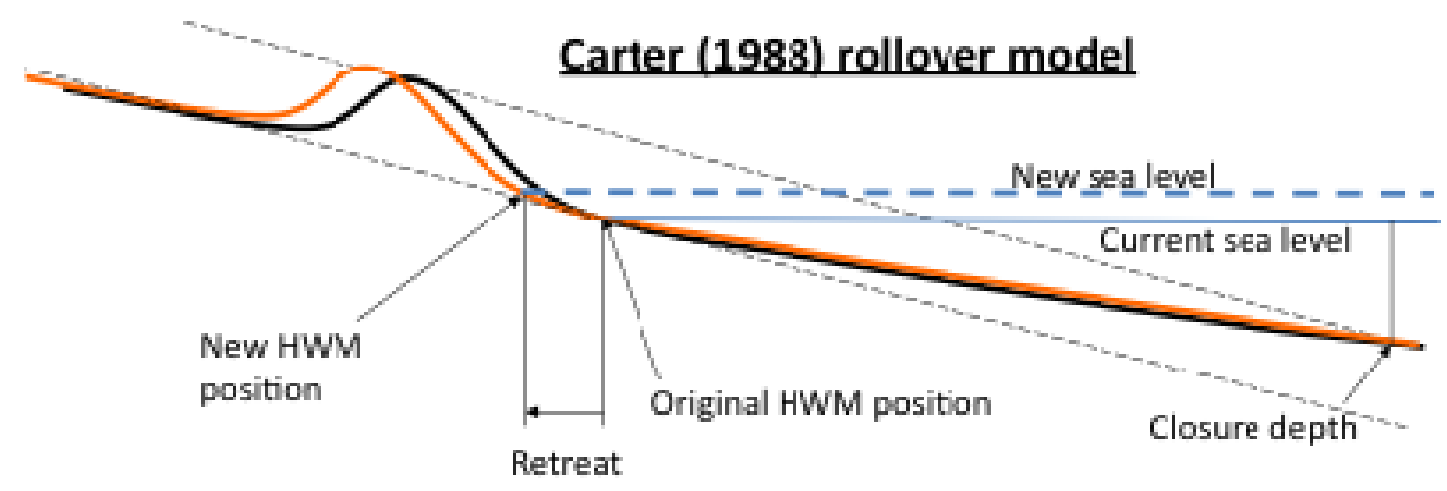

Bruun (1962)

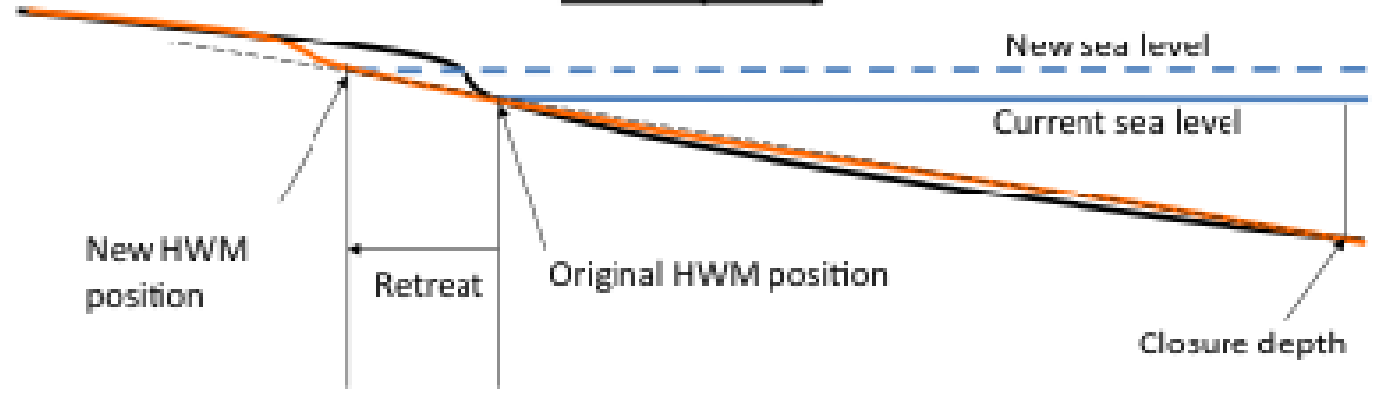

The Carter and Bruun models are simple profile transition models where continuity of sediment in the cross-shore direction is preserved. The difference between the models is the landward control point used. Carter uses the intact dune system as part of the active profile while Bruun uses the waterline. Both models define a slope of retreat as the sloping dotted line from the land control point to the closure depth. The Carter model takes into account the landward dune system as part of the sediment budget available to mitigate erosion in the cross-shore direction. The Bruun rule has been criticized by some [62-65] and supported by others [66-72], and therefore applicability should be tested prior to its application. Historically the Bruun rule has been applied in South Africa without testing its appropriateness as a suitable shoreline regression model $[73,74]$. In a parallel study to this one, the applicability of the Bruun rule in the case study region was tested. Using a series of 14 paleoshorelines from $+4 \mathrm{~m}$ to $-170 \mathrm{~m}$ above sea level, the Bruun rule was able to predict the observed retreat distance between successive paleoshorelines to within $10 \%$ of the retreat [75]. This result is acceptable given 
the simplicity of the Bruun rule and has provided some confidence in the application of the Bruun rule in this region. The shoreline retreat for the tested sample locations showed that at locations that had an intact primary dune, the predicted shoreline retreat using Carter's model was less than the retreat using the Bruun rule. However, at sites where the primary dune had been removed or did not exist, the results from both models were similar. Within the case study area, urban development has removed most of the primary dunes and therefore it was decided to apply the Bruun rule exclusively while recognizing that in areas where the primary dune still remained intact the retreat would be slightly overstated. This approach is conservative, however, it was deemed acceptable given the limitations of both models. For a full discussion of the Bruun's rule, readers are referred to [76,77].

\subsection{The Input Data}

Topography was obtained from high-resolution aerial survey. The aerial photo scale was defined as 1 in 4,600. This equates to a flying height of $800 \mathrm{~m}$ above the ground. The ground control consisted extensive existing municipal ground control points. In areas where the coverage was sparse, municipal land surveyors placed additional ground control points. The captured aerial images were developed and the diapositives scanned at a resolution of 12 microns to produce an accurate set of digital images for the photogrammetric process. The images were then triangulated and the center point of each image assigned a Global Positioning System coordinate. These center points act as auxiliary aerial control points. Using a flying height of $800 \mathrm{~m}$ the $\mathrm{X}$ and $\mathrm{Y}$ positions (planar points) were captured to an accuracy better than $\pm 10 \mathrm{~cm}$ Root Mean Squared error and the $Z$ positions had similar accuracy.

The wave run-up model requires information on the offshore wave height $\mathrm{H}_{\text {mo }}$, tidal level at the time of the storm, and distance to the $-15 \mathrm{~m}$ bathymetric contour (closure depth at this location). Data for the model were obtained for wave heights [39], tide levels and the $-15 \mathrm{~m}$ bathymetric contour from Admiralty charts [78]. The accuracy of the bathymetry on the Admiralty charts is estimated to be within $0.5 \mathrm{~m}$ of the published bathymetric contour values. The model can be run with any combination of these variables and for varying conditions i.e. a wave height of $10 \mathrm{~m}$ at HAT. For the case study, a set of variables were chosen that reflect the conditions in the case study region. Model runs assumed the state of the tide as at Mean High Water Spring (MHWS) tide at $2.01 \mathrm{~m} \mathrm{CD}$, combined with a 1:10 year storm wave height $\left(\mathrm{H}_{\mathrm{mo}}=7.1 \mathrm{~m}\right)$ and SLR of $300 \mathrm{~mm}, 600 \mathrm{~mm}$ and $1,000 \mathrm{~mm}$.

\subsection{GIS Procedures and Data Presentation}

Each stereo aerial image pair was used to generate an irregular triangular network (TIN) or Digital Terrain Model (DTM) that was exported into a Computer Aided Design (CAD) environment as a mesh of triangles. Supplementing this data were the $-15 \mathrm{~m}$ (below sea level) depth contour line and the $+0 \mathrm{~m}$ contour line. From these data a series of section lines perpendicular to the $-15 \mathrm{~m}$ depth contour line were generated and extended until they intersected the $+0 \mathrm{~m}$ contour line. These section lines were generated at approximately $5 \mathrm{~m}$ intervals along the $100 \mathrm{~km}$ of coastline. Using custom software, which runs inside the CAD environment, the wave run-up model was applied using the information for each section line. This produced a point height which was placed along the transect line where it intersected with the terrain thus gradually building up a string of points which were then joined to form a reference line. 
The amount of beach retreat was then calculated using Bruun's model [61]. The case study coastline was sectioned at $5 \mathrm{~m}$ intervals. The wave run-up model provided the elevation level of maximum wave run-up at each point. The regressed HWM position was then determined from the DTM. This retreated maximum wave run-up prediction was then used to determine the slip failure of any dune structure that existed inland of this. The slip failure angles were determined from previous data [79]. This slip failure zone was plotted on the sections and the top of the failure zone was determined. Once each cross-section had been analyzed a line joining the entire respective model results was created and shown as a line on the aerial imagery.

\subsection{Costs}

The costs associated with undertaking this work have been kept to a minimum by using only a basic amount of information. The most expensive element was the special low-level aerial survey undertaken especially for this project at ZAR 300,000 (US\$ 37,500). This cost included the aerial photography, rectification, geo-referencing and Digital Elevation Model. The modeling and freeware viewer came to ZAR 30,000 (US\$ 3,750) and internal staff costs came to approximately R25,000 (US\$ 3,125). The overall cost came to ZAR 355,000 (US\$ 44,375) or about ZAR 3,500 (US\$ 450) per kilometer.

\subsection{Presentation of the Model Results}

Often the results of GIS based models are only accessible to a limited group of GIS operators who have commercial software packages and the technical skills to work with the applications. To avoid this, the final output was created using a combination of Visual Basic and Action Script/Flash technology that can be compiled in such a way that no external or third party software is needed to run the application. Action Script/Flash is a multimedia platform that can manipulate vector and raster images and can be displayed on various computer systems and devices without the need for proprietary software. This freeware application can be distributed on DVD to any interested party to install on their personal computers. The decision to distribute the data using DVD allowed public access to the results of the study without the need for proprietary software, therefore eliminating the costs and skills associated with commercial GIS platforms. The costs of compiling and distributing the disc were below ZAR 25 (US\$ 3) which allowed enabled the municipality to distribute large numbers at very little cost. Those skilled in the use of commercial GIS packages can export the GIS shapefiles directly into those packages if they desire. The ability of the public to view the data meant that they were better informed and were able to interact in a more meaningful way. A screen shot of the SLR viewer is shown in Figure 5.

\section{Results}

All four scenarios were plotted against the aerial photography backdrop yielding the positions of the current HWM (red) and future HWM with SLR of $300 \mathrm{~mm}$ (green), $600 \mathrm{~mm}$ (purple) and 1,000 mm (yellow). A sample of the visual output is shown in Figure 6. 
Figure 5. Screen view of the standalone SLR viewer [48].

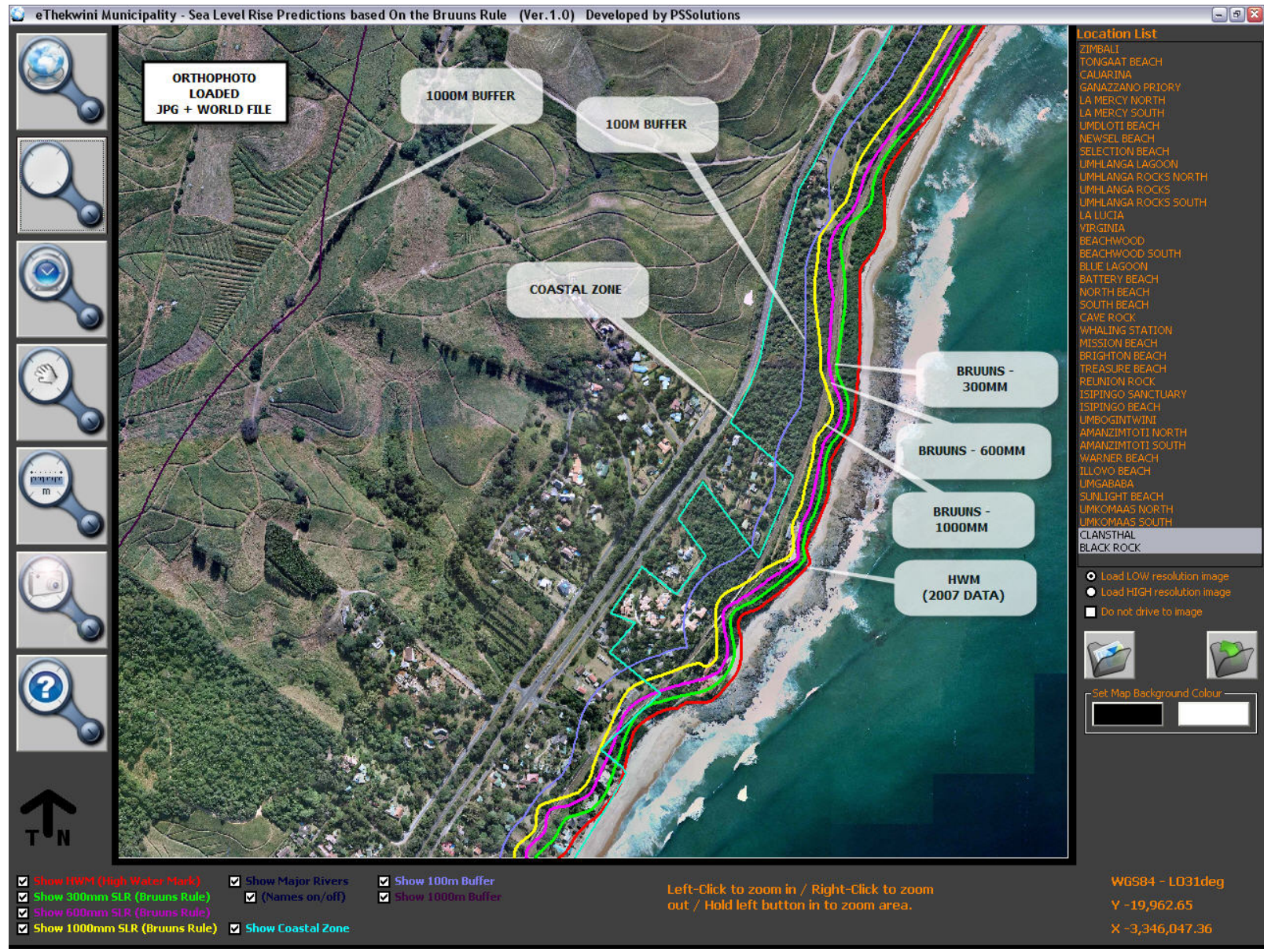

Figure 6. Present and future High Water Mark (HWM) along the Durban central beachfront [48].

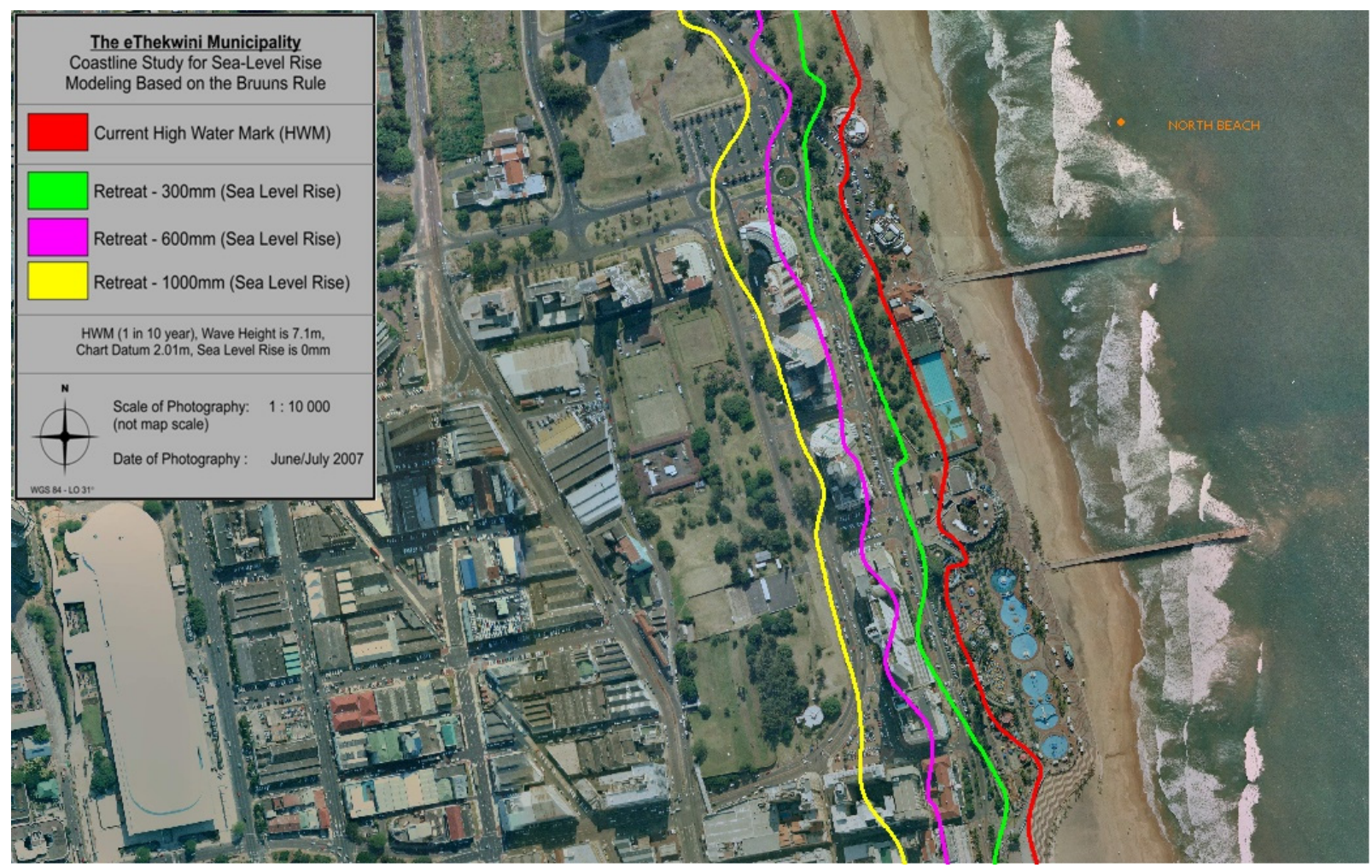




\section{Discussions on the Management Implications}

The implications for SLR along the sandy southern African shoreline will have far reaching effects extending beyond just inundation and coastal erosion. In this paper the focus is on the primary impacts as they relate to the typical types of shoreline present. A management response to SLR will need to be developed from this assessment based on each locality where infrastructural responses/interventions may be considered. A detailed investigation at each site is beyond the scope of this paper, however, some generic evaluation is possible using the study area. In order to provide some meaningful management responses, typical coastal types have been identified and the extent of possible impacts will be discussed in more detail below.

\subsection{Rocky Shores}

Rocky shorelines are represented along the southern African coastline particularly in the Western and Eastern Cape regions of South Africa. By their very nature these shorelines are relatively stable and are not subject to erosion to the extent that sandy shorelines are. The main impacts of rising sea levels will be the increase in wave run-up levels resulting in loss of vegetation at these locations.

\subsection{Undeveloped Natural Sandy Shorelines}

This type of shoreline exists in limited areas in South Africa but is more widespread in Mozambique, Tanzania and Kenya. Like rocky shores, this shoreline type is least likely to present a hazard to humans simply because they are undeveloped. Small increases in sea level result in significant regression of the high water mark. Typically these areas were inundated in the previous high stands of sea level around 6,000 years ago [80]. This type of coastline is common in Mozambique with a wide continental shelf where large portions of the flat, low elevation coastal plains are river deltas. There is sufficient land for the sea to retreat naturally with little impact on man.

From an adaptation point of view these areas need to be allowed to naturally respond to rising sea levels and perhaps the only management interventions should be to actively prevent new settlement in the potential flooding and erosion zone. A development set back line should be formulated with various SLR scenarios so that the authorities can manage development as well as prevent additional development in high-risk areas. The development set back lines must sufficiently distance from the existing shoreline to cover the risk zone. From previous experience in the region, often these developments set back lines are underestimated and are of insufficient width to perform their function. This will lead to problems with developments that are too close to the coast in the future [18]. However if these development set back lines are properly determined they have the ability to reduce risk sufficiently that the economic activities undertaken for the developments are fully realized before they are lost or need to be relocated.

\subsection{Beachfronts and Coastal Development}

Beachfronts are significant local and regional economic generators and are often constructed with significant back of beach amenities and infrastructure. The extent of these facilities has evolved over several decades and cannot simply be moved overnight. It is along this coastal type where the largest 
impacts will be experienced. Many beachfronts already have some form of sea defense in place to protect infrastructure and it is often this infrastructure that is the first to be damaged by heavy seas. Unfortunately, as is the case for many urban beachfronts, the opportunity to retreat or reconfigure the development is no longer practically possible. An adaptation response must be tailored to suit each location and its respective circumstances. For example, without any adaptation interventions the beachfront at Durban, South Africa will result in the loss of significant development and infrastructure ranging from parts of the ZAR750 million Ushaka Marine World (the fifth largest aquarium in the world when it was completed in 2003) to roads, coastal structures and tourism amenities.

In the short term it is possible to maintain the shoreline by providing additional sand from dredge sites offshore to replace and offset the increased erosion and beach reduction caused by SLR. The economic costs of this option will determine when this intervention is no longer viable. In the medium term, the decision to defend will need to be taken, since retreat will probably not be possible. The nature of the coastline will then change permanently with sea walls replacing the once sandy beaches along 'Durban's golden mile'. Other less developed beachfronts may not be so fortunate and may find that the renourishment option is too expensive and will need to move directly to a defend position. On a positive side, the development in these less developed beachfronts will be less intense and it may be possible to retreat some distance inland, effectively putting off the inevitable defend option.

\subsection{Estuaries and Mangroves}

Estuaries, often with associated mangrove stands, are highly productive systems [81] and form part of coastal ecosystems that are amongst the most threatened ecosystems in the world [82]. Their functioning is controlled by two main drivers (1) fresh water river flows and (2) the marine process of sedimentation and accretion. Some estuaries remain permanently open to the sea, some open and close depending on which factor is dominating and some remain permanently closed relying on seepage to the sea. These systems may be delicately balanced so any changes can significant impact their normal functioning e.g. frequent mouth breaching reduces the productivity while insufficient breaching results in the accumulation of pollutants leading to low oxygen levels and fish kills.

Against this background estuaries will be impacted by SLR in two ways. Firstly, as the sand bar across the estuary mouth migrates inland this has the potential to fill the estuary basin with marine sediments. This in turn will limit the available water volume and reduce the efficacy of the estuary to provide a fish nursery for marine species. Secondly, raised water levels will allow more wave energy into the mouths of estuaries and will start to negatively affect the mangrove stands that have formed within some systems, disrupting the nutrients which many organisms rely on to survive. This has a knock on effect through the food chain. Along this coastline mangroves do not survive when exposed to direct wave action and so when this occurs the mangroves will start to die off.

\subsection{Harbors}

The main Southern African harbors are located along the east shoreline of Africa i.e., Cape Town, Port Elizabeth, Coega, East London, Durban (the largest container port in Africa and 3rd in the southern hemisphere) serving as a major import/export hub for the Southern African region, Richards bay (largest coal export terminal in the southern hemisphere exporting approximately 100 million tons 
per annum), Maputo, Beira, Nacala, Dar Es Salaam and Mombasa. This string of ports provides for the flow of goods into and out of Southern and Central Africa. It is expected that a small rise in sea levels could be handled within the design capacity of the current harbors. However, should SLR be $1 \mathrm{~m}$, this will start to lead to problems. The extra water depth will result in an increase in wave energy both outside and inside the harbor. Impacts outside the harbor are like to be wave overtopping of the entrance breakwaters with loss of some of the structure leading to increased maintenance costs and additional capital costs to redesign the harbor entrance works.

Within harbors, the extra water depth will result in less freeboard along the quayside resulting in more frequent wave wash/overspray onto the working area with increased down-time and loss of productivity. With the increased wave energy, ships moored alongside the quays will not be as stable as required for the offloading of cargo. This will result is longer off-loading times, longer ship turn-around times, inefficiency at the berth-side and extra costs. Management interventions could be the fortifying of the entrance breakwater structure to reduce the increased wave energy and changes to reduce the additional wave energy penetration that affects moored ship stability at berth. In the extreme scenario of several meters' of SLR this will inundate the harbors preventing them from operating and transporting goods.

\subsection{Large Prehistoric Dune Systems}

There are several large primary dune systems, which dominate sections of the South African and Mozambique coast. The most well known of these are the red dunes of the Berea Red formation, which exists along the coast from south of Durban to beyond Maputo, Mozambique. These ancient dunes, formed around 1.2 million years ago, are aeolian deposits of fine quartz grains coated with clay containing ferric oxide giving the sand its distinctive red color. These dunes have been eroded back since the last sea level low-stand approximately 18,000 years ago [80]. As these are unconsolidated sand dunes or bluffs they are unstable. Up until the present time these unstable slopes have been identified, demarcated and development precluded from the slip area. With rising sea levels the slip failure zone will migrate inland.

Just $300 \mathrm{~mm}$ of SLR is sufficient to endanger existing developments. Figure 7 shows the main sewerage treatment works that services the Central Business District of Durban and a SLR of $300 \mathrm{~mm}$ will affect the main sewer pipeline around the tip of the Bluff. Adaptation measures could be to protect the pipeline or works through the construction of sea walls or alternatively to relocate this infrastructure on the inland side of the dune with a pipeline through the dune and to the sea outfall. Figure 8 shows the same dune formation but further south where the existing coastal forest is at risk of slipping into the sea under the scenario of $1,000 \mathrm{~mm}$ of SLR. Under these circumstance there is little one can do given the fact that urban development prevents the natural system from retreating inland. 
Figure 7. Sea level rise scenarios for the Central sewerage treatment works in Durban [48].

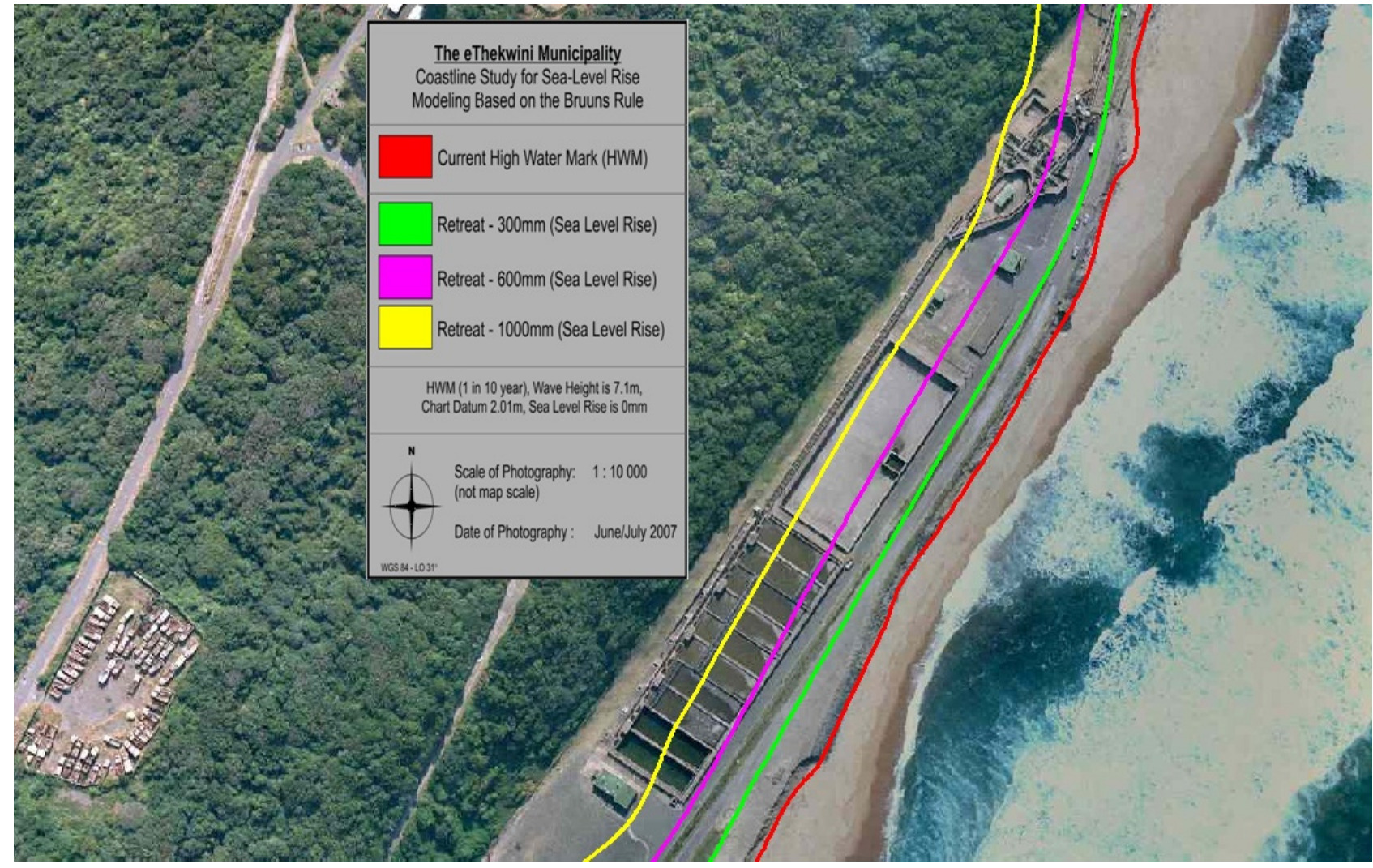

Figure 8. Slope failure of dunes with $1000 \mathrm{~mm}$ of sea level rise and loss of coastal forest [48].

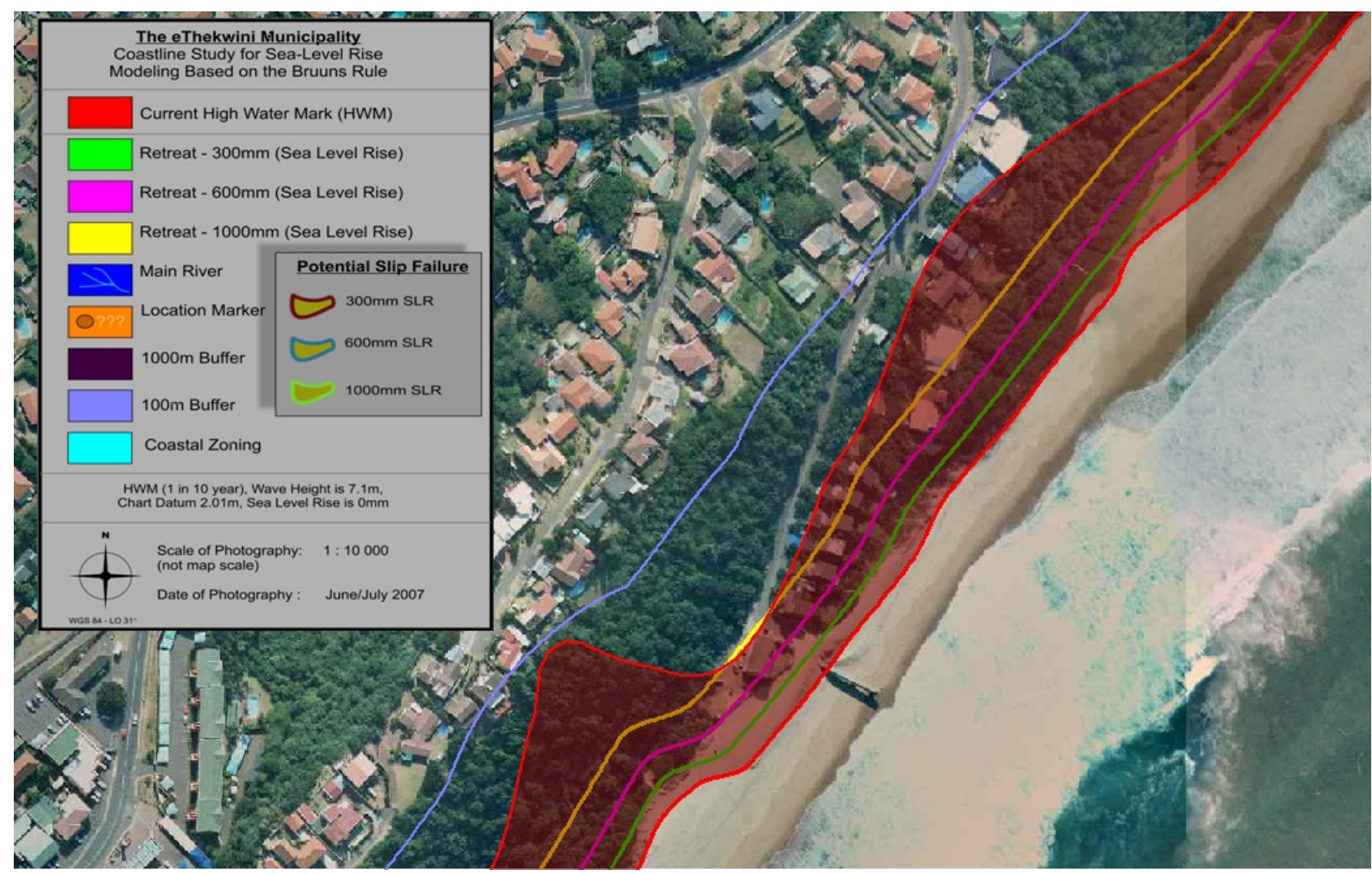




\subsection{Armored or Fortified Coastlines}

Shorelines that have previously been fortified using sea wall of other defense systems will not be immune from attack. Increases in water depth as a result of SLR will allow increased wave energy to penetrate closer inshore. This increased wave energy could exceed the original designers design condition, if so the structure will be subjected to more wave energy then it is capable of withholding, resulting in partial or full failure of the structure. Adaptation to increased SLR would be to check the design parameters of existing critical infrastructure where failure could result in severe financial, social and environmental costs. New infrastructure adaptation is easier as these additional wave forces can be designed into the structure at the initial stage.

In all the developed cases discussed above, the need to provide some recreational activities close to the sea has to be tempered with the risks associated with this approach. In these circumstances managed retreat would be the preferred international best practice action in this case [83] but as that is ruled out the need arises for a multi-layered approach to the problem of coastal flooding and erosion. The rate of SLR has been predicted to increase over time and so in the next decades there exists a "window of opportunity" to provide some infrastructure close to the hazard zone when sea levels are still close to current levels.

This raises the question as to what should/could be allowed in this zone that does not place undue financial hardship on the owners of the infrastructure when SLR starts to impact them. By balancing the risk of failure against the value of the infrastructure it is possible to review what is suitable in the various risk zones or not. This is outlined in Table 3.

Table 3. Recommended amount of sea level rise to be incorporated into the design of new infrastructure [84].

\begin{tabular}{|c|c|c|c|}
\hline $\begin{array}{c}\text { Value of infrastructure } \\
\text { in South African Rands (ZAR) }\end{array}$ & $\begin{array}{c}\text { Life of } \\
\text { infrastructure }\end{array}$ & $\begin{array}{l}\text { Impacts of failure of the } \\
\text { infrastructure }\end{array}$ & $\begin{array}{c}\text { Planned amount } \\
\text { of sea level rise }\end{array}$ \\
\hline $\begin{array}{l}\text { Low } \\
\text { (up to ZAR } 2 \text { million) } \\
\text { i.e., Recreational facilities, car } \\
\text { parks, board walks, temp beach } \\
\text { facilities }\end{array}$ & $\begin{array}{l}\text { Short term } \\
\text { Less than } \\
20 \text { years }\end{array}$ & $\begin{array}{l}\text { Low } \\
\text { Minor inconvenience, } \\
\text { alternative facilities in close } \\
\text { proximity, short rebuild times }\end{array}$ & $0.3 \mathrm{~m}$ \\
\hline $\begin{array}{l}\text { Medium } \\
\text { (ZAR } 2 \text { million to } 20 \text { million) } \\
\text { Tidal pools, piers, recreational } \\
\text { facilities, sewerage pump stations. }\end{array}$ & $\begin{array}{l}\text { Short to } \\
\text { Medium Term } \\
\text { Between } 20 \text { and } \\
50 \text { years }\end{array}$ & $\begin{array}{l}\text { Medium } \\
\text { Local impacts, loss of } \\
\text { infrastructure and property }\end{array}$ & $0.6 \mathrm{~m}$ \\
\hline $\begin{array}{l}\text { High } \\
\text { (ZAR } 20 \text { million to } 200 \text { million) } \\
\text { Beachfronts, small craft harbors, } \\
\text { Residential homes, sewerage } \\
\text { treatment works. }\end{array}$ & $\begin{array}{l}\text { Medium to } \\
\text { Long Term } \\
\text { Between } 50 \text { and } \\
100 \text { years }\end{array}$ & $\begin{array}{l}\text { High } \\
\text { Regional impacts, loss of } \\
\text { significant infrastructure and } \\
\text { property }\end{array}$ & $1.0 \mathrm{~m}$ \\
\hline $\begin{array}{l}\text { Very High } \\
\text { (greater then ZAR } 200 \text { million) } \\
\text { Ports, desalination plants, nuclear } \\
\text { power stations }\end{array}$ & $\begin{array}{l}\text { Long term } \\
\text { In excess of } \\
100 \text { years }\end{array}$ & $\begin{array}{l}\text { Very High } \\
\text { Major disruption to the regional } \\
\text { and national economy, failure } \\
\text { of key national infrastructure }\end{array}$ & $2.0 \mathrm{~m}$ \\
\hline
\end{tabular}


The approach in Table 3 takes a balanced view of risks and has been recommended for use in South Africa.

\section{Conclusions}

The results of this paper show that the zone of high risk above the HWM within the coastal zone can be relatively easily described and mapped. This provides the basic information that decision makers require when planning any new and existing activity within the coastal zone. The results show that each portion of the coastline will be affected differently by SLR. These results can be shared with a much broader grouping of society than had this information been only available in a conventional GIS application. Key management issues arising from this work have been identified for each coastal type and it has been relatively easy to describe these changes generically for each coast type.

\section{Acknowledgments}

AAM wishes to thank Petrie Swart for his assistance in the GIS mapping and the preparation of the GIS viewer interface and the eThekwini Municipality for the use of the aerial photography.

\section{References}

1. O’Connor, M.; Cooper, J.A.G.; Jackson, D.W.T. Decadal behavior of tidal inlet-associated beach systems, Northwest Ireland, in relation to climate forcing. J. Sediment. Res. 2011, 81, 38-51.

2. Cooper, J.A.G.; Jackson, D.W.T.; Navas, F.; McKenna, J.; Malvarez, G. Identifying storm impacts on an embayed, high-energy coastline:examples from western Ireland. Mar. Geol. 2004, 210, 261-280.

3 IPCC. Climate Change 1995: The Scientific Basis; Houghton, J.T., Meira Filho, L.G., Callander, B.A., Harris, N., Kattenberg, A., Maskell, K., Eds.; Cambridge University Press: New York, NY, USA, 1996; p. 572.

4. IPCC. Climate Change 2001: The Scientific Basis; Houghton, J.T., Ding, Y., Griggs, D.J., Noguer, M., van der Linden, P.J., Dai, X., Maskell, K., Johnson, C.A., Eds.; Cambridge University Press: Cambridge, UK, 2001; p. 881.

5. Stern, N. Stern Review on the Economics of Climate Change; Her Majesty's Treasury, Cambridge University Press: Cambridge, UK, 2006; p. 700.

6. IPCC. Climate Change 2007: The Physical Basis-Summary for Policy Makers; Cambridge University Press: Cambridge, UK, 2007; p. 18.

7. Mather, A.A. Linear and nonlinear sea level changes at Durban, South Africa. S. Afr. J. Sci. 2007, 103, 509-512.

8. Mather, A.A.; Garland, G.G.; Stretch, D.D. Southern African sea levels: Corrections, influences and trends. Afr. J. Mar. Sci. 2009, 31, 145-156. 
9. Midgley, G. Chapman, R.A.; Hewitson, B.; Johnston, P.; de Wit, M.; Ziervogel, G.; Mukheibir, P.; van Niekerk, L. Tadross, M.; van Wilgen, B.W.; et al. A Status Quo, Vulnerability and Adaptation Assessment of the Physical and Socio-Economic Effects of Climate Change in the Western Cape. Report to the Western Cape Government; Cape Town, South Africa, 2005, CRIR Report Number ENV-S-C-2005-073, Stellenbosch, South Africa.

10. CSIR. Climate Future for Durban: Revised Report; Roberts, D., Mather, A.A., Maganlal, M., Eds.; CSIR: Durban, South Africa, 2006.

11. Golder Associates. Report on Urban Integrated Assessment Framework for Climate Change: Workplan for 2008-2009-Finalisation of the Integrated Assessment Tool. Durban, South Africa 2008, Report Number 10290-Dur-4-Phase 3 Integrated Assessment Workplan.

12. Golder Associates. Progress Report on Preparation of an Urban Assessment Framework for Climate Change. Report for the eThekwini Municipality, Durban, South Africa, 2008, 10290-CCUIAF-Progress Report.

13. Golder Associates. eThekwini Municipality: Integrated Assessment Tool for Climate Change Impacts, Durban, South Africa, 2009, Progress Report, 10290-8871-6-E.

14. eThekwini Municipality. High Water Mark, Coastal Erosion and Hazard Delineation Model for the Durban Coastline; eThekwini Municipality: Durban, South Africa, 2009; p. 12.

15. Laqua, R. Global Climate Change-A Sea-Level Rise Risk Assessment; Report for the City of Cape Town, Cape Town, South Africa, 2008.

16. Hewitson, B. Potential Changes in Western Cape Climate Due to Global Warming. Presentation to the Western Cape Provincial government, CSAG, University of Cape Town, South Africa, 2006.

17. Theron, A.K. Analysis of potential coastal zone climate changes and possible response options in the Southern African region. In Proceedings of the IPCC/ TGICA Regional Experts Meeting on Climate Change, Nadi, Fiji, 20-22 June 2007.

18. Harris, L.R. The Ecological Implications of Sea Level Rise and Storms for Sandy Beaches in KwaZulu-Natal. Master Thesis. University of KwaZulu-Natal, Durban, South Africa 2008; p. 171.

19. Brundrit, G.B. Special adviser in oceans and climate change. Department of Environmental Affairs, Oceans and Coasts, Cape Town, South Africa, 2009 ; Personal communication.

20. Theron, A.K. Coastal engineering researcher. Council for Scientific and Industrial research, Stellenbosch, South Africa. 2009; Personal communication.

21. Jevrejeva, S. Global sea level set to rise above IPCC forecast. Geographical June 2008; p. 11.

22. Meteo France; Toulouse, France. 2008. Available online: http://www.meteo.fr (accessed on 20 February 2012).

23. Woodworth, P.L.; Aman, A.; Aarup, T. Sea level monitoring in Africa. Afr. J. Mar. Sci. 2008, 29, 321-330.

24. NASA. Available online: http://visibleearth.nasa.gov (accessed on 1 February 2012).

25. Kovács, Z.P.; du Plessis, D.B.; Bracher, P.R.; Dunn, P.J.; Mallory, G.C.L. Documentation of the 1984 Domoina Floods; Technical Report TR 122; Department of Water Affairs, Pretoria, South Africa, 1985.

26. File:Southwest Indian Ocean cyclone tracks 1980-2005.jpg. Wikimedia Commons, 27 February 2007. Available online: http://en.wikipedia.org/wiki/File:Southwest_Indian_Ocean_cyclone_ tracks_1980-2005.jpg (accessed on 1 February 2012). 
27. Taljaard, J.J. Cut-Off Lows in the South African Region; Technical Paper Number 14; South African Weather Bureau, Pretoria, South Africa, 1985.

28. Alexander, W.J.R. Flood Risk Reduction Measures; Department of Civil Engineering, University of Pretoria: Pretoria, South Africa, 2000; p. 226.

29. Hunter, I. The Cut-off Low of 17-21 March 2007 off the East Coast of South Africa; South African Weather Service: Pretoria, South Africa, 2007.

30. Mather, A.A. Sea level rise and coastal erosion: Are municipalities prepared? IMIESA March 2008, pp. 49-70.

31. South African Weather Service. 2008. Available online: http://www.weathersa.co.za (accessed on 20 February 2012).

32. Corniche, E. Presidente do Conselho Municipal de Maputo (Mayor of Maputo, Mozambique), Maputo, Mozambique, 2007; Personal communication.

33. Mather, A.A.; Stretch, D.D.; Garland, G.G. Predicting extreme wave run up on natural beaches for coastal planning and management. Coast. Eng. J. 2011, 53, 87-109.

34. Mavume, A.F.; Rydberg, L.; Rounault, M.; Lutjeharms, J.R.E. Climatology and landfall of Tropical Cyclones in the South-West Indian Ocean. West. Indian Ocean J. Mar. Sci. 2009, 8, $15-36$.

35. Polomé, P.; Marzetti, S.; van der Veen, A. Economic and social demands for coastal protection. Coast. Eng. 2005, 52, 819-840.

36. Kay, R.; Alder, J. Coastal Planning and Management; E \& FN Spon: New York, NY, USA, 1999.

37. Jukes, L.M. A bone-bearing beachrock at Umbogintwini, Natal. Trans. Geol. Soc. S. Afr. 1976, 79, 301-303.

38 Coastal Engineering Manual; US Army Corps of Engineers: Washington, DC, USA, 2008; p. 2817.

39. CSIR. Wave Conditions off Durban; Stellenbosch, South Africa; 2000, CSIR Report ENV-S-C2000-018.

40. Rahmstorf, S. A semi-empirical approach to projected future sea-level rise. Science 2007, 315, 368-370.

41. Meier, M.F.; Dyurgerov, M.B.; Rick, U.K.; O’Neel, S.; Pfeffer, W.T.; Anderson, R.S.; Anderson, S.P.; Glazovsky, A.F. Glaciers dominate eustatic sea level rise in the 21 st century. Science 2007, 317, 1064-1067.

42. Church, J.A.; White, N.J. A 20th century acceleration in global sea-level rise. Geophys. Res. Lett. 2006, 33, doi:10.1029/2005GL024826.

43. Jevrejeva, S.; Moore, J.C.; Grinsted, A.; Woodworth, P.L. Recent global sea level acceleration started over 200 years ago? Geophys. Res. Lett. 2008, 35, doi:10.1029/2008GL033611.

44. Schubert, R.; Schellnhuber, H.-J.; Buchmann, N.; Epiney, A.; Grießhammer, R.; Kulessa, M.; Messner, D.; Rahmstorf, S.; Schmid, J. The Future Oceans-Warming up, Rising High, Turning Sour; German Advisory Council on Global Change (WBGU): Berlin, Germany, 2006; p. 110.

45. Delta Commission 2008. Working Together with Water; Delta Commission: Amsterdam, Holland, 2008; p. 138.

46. Heberger, M.; Cooley, H.; Herrera, P.; Gleick, P.H.; Moore, E. Report on the Impacts of Sea Level Rise on the Californian Coast; Pacific Institute: Oakland, CA, USA, 2009; p. 113. 
47. Mather, A.A. Sea level changes in the Western Indian Ocean region. In Proceedings of the WIOMSA Conference, Grand Baie, Mauritius, 21-23 March 2011.

48. Mather, A.A. Projections and Modeling Scenarios for Sea Level Rise at Durban, South Africa; Internal Report of the eThekwini Municipality, Durban, South Africa, 2009; p. 25.

49. Meier, M.F.; Dyurgerov, M.B.; Rick, U.K.; O’Neel, S.; Pfeffer, W.T.; Anderson, R.S.; Anderson, S.P.; Glazovsky, A.F. Glaciers dominate eustatic sea level rise in the 21 st century. Science 2007, 317, 1064-1067.

50. Stockdon, H. F. Predicting the Longshore-Variable Coastal Response to Hurricanes. Ph.D. Dissertation. Oregan State University, Corvallis, OR, USA, 2006; p. 117.

51. Hunt, I.A. Design of seawalls and breakwaters. J. Waterw. Harb. Div. 1959, 85, 123-152.

52. Sallenger, A.H. Storm impact scale for barrier islands. J. Coast. Res. 2000, 16, 890-895.

53. Ruggiero, P.; Holman, R.D.; Beach, R.A. Wave run-up on a high energy dissipative beach. J. Geophys. Res. 2004, 109, doi:10.1029/2003JC002160, 1-12.

54. Jackson, D.W.T.; Cooper, J.A.G.; del Rio, L. Geological control of beach morphodynamic state. Mar. Geol. 2005, 216, 297-314.

55. Jackson, D.W.T.; Cooper, J.A.G. Geological control on beach form: Accommodation space and contemporary dynamics. J. Coast. Res. 2009, 1, 69-72.

56. Holman, R.A. Extreme value statistics for wave run-up on a natural beach. Coast. Eng. 1986, 9, 527-544.

57. Stockdon, H.F.; Holman, R.D.; Howd, P.A.; Sallenger, A.H. Empirical parameterization of setup, swash and run-up. Coast. Eng. 2006, 53, 573-588.

58. Nielsen, P.; Hanslow, D.J. Wave run-up distributions on natural beaches. J. Coast. Res. 1991, 7, 1139-1152.

59. Douglass, S.L. Estimating extreme values of run-up on beaches. J. Water. Port Coast. Ocean Eng. 1992, 118, 220-224.

60. Carter, R.W.G. Coastal Environments; Academic Press: London, UK, 1988; p. 609.

61. Bruun, P. Sea-level rise as a cause of shore erosion. J. Waterw. Harb. Div. 1962, 88, 117-130.

62. Pilkey, O.H. Can we predict the behavior of sand: In a time and volume framework for use to humankind? J. Coast. Res. 1993, 9, iii-iv.

63. Davidson-Arnott, G.D. Conceptual model of the effects of sea level rise on sandy coasts. J. Coast. Res. 2005, 21, 1166-1172.

64. Stive, M.J.F. How important is global warming for coastal erosion. Clim. Change 2004, 64, $27-39$.

65. Cooper, J.A.G.; Pilkey, O.H. Sea level rise and shoreline retreat: Time to abandon the Bruun rule. Glob. Planet Change 2004, 43, 157-171.

66. Dubois, R.N. Nearshore evidence in support of the Bruun Rule on shore erosion. J. Geol. 1976, 84, 485-491.

67. Dubois, R.N. Hypothetical shore profiles in response to rising water level. In Proceedings of the Per Bruun Symposium. International Geographical Union Commission on the Coastal Environment, Schwartz, M.L., Fisher, J.J., Eds.; Newport, RI, USA, November 1979 ; pp. 13-31. 
68. Fisher, J.J. Holocene sea level rise, shore-line erosion and the Bruun Rule, and overview. In Proceedings of the Per Bruun Symposium. International Geographical Union Commission on the Coastal Environment, Schwartz, M.L., Fisher, J.J., Eds.; Newport, RI, USA, November 1979; pp. 1-5.

69. Fisher, J.J. Shoreline erosion, Rhode Island and North Carolina Coasts, test of Bruun Rule. In Proceedings of the Per Bruun Symposium. International Geographical Union Commission on the Coastal Environment, Schwartz, M.L., Fisher, J.J., Eds.; Newport, RI, USA, November 1979; pp. 32-54.

70. Rosen, P.S. A regional test of the Bruun Rule on shoreline erosion. Mar. Geol. 1978, 26, 7-16.

71. Rosen, P.S. An application of the Bruun Rule in the Chesapeake Bay. In Proceedings of the Per Bruun Symposium. International Geographical Union, Commission on the Coastal Environment, Schwartz, M.L., Fisher, J.J., Eds.; Newport, RI, USA, November 1979; pp. 55-62.

72. Weggel, R. A Method for Establishing Long-Term Erosion Rates from a Long-Term Rise in Water Level; CETA 79-2; Coastal Engineering Research Center: Ft. Belvoir, VA, USA, 1979.

73. Theron, A.K. Sea level rise, impacts and the use of Bruun's erosion rule. J. S. Afr. Inst. Civ. Eng. 1994, 36, 6-10.

74. DEA\&DP. Development of a Methodology for Defining and Adopting Coastal Development Setback Lines; Report undertaken by WSP Africa Coastal Engineers, Stellenbosch, South Africa, 2010, p. 83.

75. Mather, A.A. The applicability of Bruun's Rule in South Africa, 2012, in submit.

76. Bruun, P. The Bruun Rule of erosion by sea-level rise: A discussion on large-scale two- and three- dimensional usages. J. Coast. Res. 1988, 4, 627-648.

77. Bruun, P. A re-evaluation of Bruun's Rule and supporting evidence. J. Coast. Res. 1993, 9, 282-284.

78. South African Navy. 2007 South African Tide Tables; South African Navy Hydrographic Office: Simons Town, South Africa, 2007.

79. Unpublished Data; ethekwini Municipality: Durban, South Africa, 2009.

80. Ramsay, P.; Cooper, J.A.G. Late Quaternary sea level change in South Africa. Quat. Res. 2002, 57, 82-90.

81. Forbes, A.T.; Demetriades, N.T. Estuaries of Durban, KwaZulu-Natal, South Africa 2009 Report; eThekwini Municipality, Durban, South Africa, 2009; p. 224.

82. Millennium Ecosystem Assessment. Ecosystem and Human Well-Being: Biodiversity Synthesis; World Resources Institute: Washington, DC, USA, 2005.

83. Breetzke, T.; Parak, O.; Cilliers, L.; Mather, A.; Colenbrander, D. "Living with coastal erosion" the KwaZulu-Natal best practice response strategy. In Proceedings of the International Association of Impact Assessors (South Africa) Conference, Bela Bela, South Africa, August 2008.

84. Mather, A.A. Stormy sea ahead: Planning for sea level rise. In Proceeding of the South African Planning Institution Conference, Durban, South Africa, 18-21 April 2010.

(C) 2012 by the authors; licensee MDPI, Basel, Switzerland. This article is an open access article distributed under the terms and conditions of the Creative Commons Attribution license (http://creativecommons.org/licenses/by/3.0/). 